DOI https://doi.org/10.25045/k.nurubay.pirist-1

ISBN 9789952536294

ORCID iD https://orcid.org/0000-0001-6958-5412

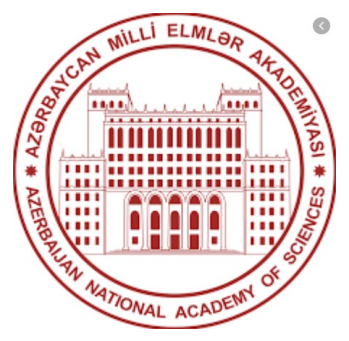

Azərbaycan Milli Elmlər Akademiyası

Azərbaycan Respublikası Elmi Tədqiqatların Olaqələndirilmə Şurası

Klinik, Regenerator və Translyason Təbabət üzrə Elmi Şura

\title{
TIBBI TODQIQATLRIN PIRORITET ISTIQAMəTLəRI Və SAHəLəRI
}

Azərbaycan Respublikası Elmi Tədqiqatların əlaqələndirilmə Şurasının Klinik, Regenerator və Translyason Təbabət üzrə Elmi Şurasının 10.02.2020 tarixli qərarı ilə təsdiq edilmişdir.

Bakı, 2020 
Bu sənədin layihəsi və prinsipləri 2016-2019-cu illər ərzində aşağıdakı elmi təşkilatlarda müzakirə olunmuş, rəylər və təkliflər nəzərə alınaraq tərtib edilmişdir:

- AMEA-nın ümumi yığıncaqları

- AMEA-nın Rəyasət Heyətinin toplantıları

- AMEA Biologiya və Tibb Bölməsinin yığıncaqları

- AMEA və Səhiyyə Nazirliyinin ortaq Sesiyaları

- Azərbaycan Respublikası Elmi Tədqiqatların əlaqələndirilmə Şurasının Tibb üzrə Problem Şurasının iclasları

- AMEA Biologiya və Tibb Bölməsi ilə Azərbaycan Tibb Universitetinin ortaq toplantıları

- Azərbaycan Tibb Universiteti

- Azərbaycan Həkimləri Təkmilləşdirmə Institutu

- Milli Onkologiya Mərkəzi

- Carrahiyya Elmi Mərkəzi

- Ağciyər xəstəlikləri ETi

- Hematologiya ETi

- Oftalmologiya ETi

- Travmatologiya ETi

- Pediatriya ETI

- Tibbi Bərpa ETi

- Ginekologiya ETi

- Profilkatik təbəbət ETI

- Kardiologiya ETi

- Seçenov Universitetinin Bakı filialı

- AMEA-nın Molekulyar biologiya və Biotexnologiyalar Institutu

- AMEA-nın Genetik Ehtiyyatlar İnstitutu

- AMEA-nın Fiziologiya İnstitutu

- AMEA-nın Botanika institutu

- AMEA-nın Zoologiya İnstitutu

- AMEA-nın Mikrobiologiya Institutu

- AMEA-nın İnformasiya Texnologiyaları Institutu

- AMEA-nın Biofizika İnstitutu

- AMEA-nın Dendrologiya İnstitutu 


\section{METADATA}

Type Book

Title Tibbi tədqiqatIrın piroritet istiqamətləri və sahələri

Editor Bayramov Nuru Yusif oğlu

Edition 1

Authors Bayramov Nuru Yusifoğlu, Cəfərli Rasim

\section{Experts}

Year

10.02.2020

Pages

Abstract Burada Azərbaycan tibb elminin yaxın gələcəkdəki piroritet istaqamətləri, sahələri və prinsipləri barədə qısa məlumat verimişdir. Bu istiqamətlər, sahələr və prinsiplər Azərbaycan Milli Elmlər Akademiyası, Azərbaycan Respublikası Elmi Tədqiqatların כlaqələndirilmə Şurası və Klinik, Regenerator və Translyason Təbabət üzrə Elmi Şurasının rəhbərliyi ilə ölkəmizdəki elmi-tibbi təşkilatlarda və toplantılarda aparılan müzkirələr nəticəsində müəyyən edilmişdir. İnnovativlik, multidissiplinarlıq və çoxmərkəzlilik əsas peinsiplər kimi qəbul edilmişdir. Regenerator tibb və kök hüceyrələr, molekulyar biologiya və biomarkerlər, genom və genetik markerlər, yüksək texnologiyalar və suni intellekt, eksperimental nəticələrin klinik təbəbətə tətbiqi, mikrobiota və mikrobiom, sübutlu təbəbət və yeni dərman preparatlarının hazılrnması yaxın gələcəkdə ölkəmizdə tibb elminin piroritet istiqamətlərini təşkil edəcəkdir. Onkoloji, ürək-damar, endokrin və metabilok, ağciyər, qaraciyər, nevroloji, pediatrik, psixatrik, immunoloji və infeksiyon xəstəliklərin profilaktikası, erkən diaqnostikası, müalicəsi və proqnozlaşdırlması, profilaktik və reproduktiv təbabət, herintologiya, transplantasiya, ekologiya və 
insan sağlamlığı, epidemioloji və sosioloji tədqiqatlar işə tibbi araşdırmaların strateji sahələri kimi qəbul edilmişdir.

Keywords Azərbaycanda tibb elmi, tibbi tədqiqatlar, piroritet istaqamətlər, piroritet sahələr, prinsiplər, innovativ, multidissiplinar, çoxmərkəzli, regenerator tibb, kök hüceyrələr, molekulyar biologiya, biomarkerlər, genom, genetik markerlər, yüksək texnologiyalar, suni intellekt, translyason tibb, mikrobiota, mikrobiom, sübutlu təbəbət.

City Baku

Publisher AMEA, Azərbaycan Respublikası Elmi Tədqiqatların Jlaqələndirilmə Şurası, Klinik, Regenerator və Translyason Təbabət üzrə Elmi Şurası

Language Azerbaijani

Type of Textbook

work

URL

Web site www.bck.az

DOI $\quad 10.25045 / k \cdot n u r u b a y . p i r i s t-1$

ISBN 9789952536294

ORCID iD https://orcid.org/0000-0001-6958-5412 


\section{TIBB ELMININ INKIŞAF ISIQAMəTLORi}

\section{MəQSOD}

Tibb elminin məqsədi insan orqanizmində baş verən fizoloji və patoloji proseslərin nəzəri əsaslarını, bu proseslərə təsir edən faktorları və vasitələri öyrənmək, əldə olunan nəticələri sağlanmlığın qorunması, xəstəliklərin diaqnostikası, müalicəsi və proqnozlaşdırıması üçün tətbiq etməkdir. Hazırkı mərhələdə konkret məqsəd əhalinin sağlamlığının qorunması üçün elmi tədqiqatları innovativ, yüksək texnologiyaların yaradılmasına və tibbi praktikaya tətbiqinə yönləndirməkdir.

\section{PIRORITET ELMI TODQIQAT ISTIQAMOTLORI}

Piroritet elmi tədqiqat istiqamətləri dedikdə elmi-praktik problemlərin həlli üçün innovativ (yenilikçi) nəticələrin əldə edilmə ehtimalı yüksək olan təqdiqat obyektləri və prosesləri nəzərdə tutulur. Regenerativ tababat, genomika, molekulyar biologiya, yüksak texnologiyalar, translyasyon va subutlu tababat hazırda dünya tibb elminin piroritet istiqamətləri kimi görünməkdədir.

\section{Regenerator təbəbət}

\section{Osaslandırma}

Regenerator təbəbət dedikdə çoxaltma vasitələrinin köməyi ilə hüceyrələrin, toxumaların və ya orqanların istehsalı (yaradılması) və tibbi məqsədlə istifadəsi nəzərdə tutulur (zədələnmiş toxuma və orqanları bərpası və ya əvəz edilməsi). İstehsal prosesi orqanizmin daxilində və xaricində ola bilər. Çoxaltma vasitələrinə aşağıdakı 4 əsas ünsür və ya onların kombinasiyası aid edilir:

- kök hüceyrələr

- ekstrasellular matriks (skafold, çatı)

- genetik manipulyasiya

- böyümə faktorları 
Bu vasitələrin köməyi ilə regenerator təbəbətdə aşağıdakı məhsullar istehsal oluna bilir:

- hüceyrə populyasiyasları

- eksosomlar

- skafold

- toxumalar

- orqanoidlər

- orqanlar.

Orqanizmdə mövcud olan üç qrup hüceyrələrdə biri kök hüceyrələrdir, digərləri nəsil (yumurta hüceyrələri və spermatozoidlər) və yetkin (diferensiasiya olunmuş) hüceyrələrdir. Kök hüceyrələr normal halda funksiya göstərməyən ehtiyyat hüceyrələridir, zərurət olduqda asimmetrik bölünərək fizioloji və patoloji proseslərə təsir edirlər. Asimmetrik bölünmədə kök hüceyrə ikiyə bölünür, hüceyrələrdən biri kök hüceyrə kimi ehtiyatda qalır (özünü yeniləmə), digəri isə yetkin hüceyrəyə diferensiasiya edir və ya humoral faktorlar ifraz edir. Diferensasiya yolunu tutan hüceyrələr zədələnmiş hüceyrələri əvəz edə bilirlər (transformasiya mexanizmi). Kök hüceyrələrin fizioloji və patoloji proseslərə təsirinin ikinci mexanizmi parakrin mexanimdir ki, bu halda kök hüceyrələr requlyator maddələrlə zəngin olan qovucquqlar (eksosomlar) ifraz edərək ətrafdakı hüceyrələrə təsir göstəririlər. Eksosomların tərkibində böyümə stimulyatorları, iltihab-yönlü, iltihab-əlehinə sitokinlər və s. ola bilir. Kök hüceyrələrin əmələ gəlmə vaxtına, yerinə görə müxtəlif tipləri var (embrional, fetal, progenitor, mezenximal, hemopoetik və s.) və tipindən asılı olaraq xüsusiyyətləri də dəyişir. Məsələn, embrional kök hüceyrələrin transformasiya xüsusiyyəti, mezensximal kök hüceyrələrin isə parakrin xüsusiyyəti daha yüksəkdir.

Regenerator təbəbətdə istifadə edilən ikinci önəmli vasitə ekstrasellular matriksdir (toxuma skeleti və ya çatısı, scaffold). Matriks təbii və ya süni ola bilər. Birləşdirici liflərdən və hüceyrərası maddədən təşkil olan bu matriks hüceyrənin qidalanması və mübadiləsi üçün şərait yaratmaqla yanaşı sklet-çatı rolu oynayaraq hüceyrələrin düzülüşünü - toxumanın quruluşunu təmin edirlər. Toxuma skleti kök hüceyrələrdən toxumanın və orqanın istehsalı üçün vacib element sayılır. Bu olmazsa orqanoid adlanan hüceyrə kütləsi meydana gəlir. 
Böyümə faktorlarının əksəriyyəti zülal təbiətli maddələrdir, spesifik reseptorlara bağlandıqda hüceyrənin bölünməsi prosesini başladırlar. Bunların çoxsaylı nümayəndələri var, epitelial, angiogenetik, hepatosit, fibroblast, hemopoetik, eritrositar, trombositar və s.

Regenerator təbəbətin digər vasitəsi gen manipulyasiyasıdır, adətən hüceyrə bölünməsini başladan genləri aktivləşdirərək toxuma regenerasiya etdirilir.

Regenerator təbəbət ən sürətlə inkişaf edən sahələrdən biri kimi nəzəri və klinik təbəbətin bütün sahələrində geniş öyrənilməkdə və tətbiq sahələri gedərək genişlənməkdədir.

Regenerator təbəbətin vasitələri və məhsullarının geniş tətbiqi sayəsində bir çox sağalmayan və ya sağalması çətin olan patologiyaları müalicə etmək imkanı yaranmışdır: böyük yanıqlarda və trofiki xoralarda "süni dəri", çapıqların "müalicəsi" üçün fibroblastlar, sümük iliyi transplantasiyası üçün hemopoetik kök hüceyrə, ekstrakorporal mayalanma, rəddetmənin müalicəsi üçün mezenximal kök hüceyrələr, Kron xəstəliyi, autoimmun hepatit və s kimi autoimmun xəstəliklərin müalicəsi üçün kök hüceyrə ekzosomları, neyrodegenerativ xəstəliklərdə kök hüceyrələr, vtitliqonun müalicəsi üçün melanostilər və s.

\section{Regenerator tababatin piroritet tadqiat mövzuları}

- Toxuma mühəndisliyi- süni və təbii çatılar (skafoldlar), kök hüceyrələr və böyümə faktorları istifadə etməklə toxumaların istehsalı və klinik təbabətdə istifadəsi.

- Orqan istehsalı - süni və ya təbbi çatılar və kök hücerələr istifadə etməklə ürək, böyrək, qaraciyər, bronx, öd yolu, damar və s. kimi orqanların istehsalı və klinik təbabətdə istifadəsi.

- Skafoldların axtarışı - orqan və toxumaların istehsalı üçün süni və təbii matrikslərin hazırlanması və tətbiqi.

- Kök hüceyrələrin və məhsullarının kəskin və xroniki orqan yetməzliklərində, tətbiqi. 
- Kök hüceyrələrin və məhsullarının, onkoloji, autoimmun, kardiovaskulyar, metabolik, genetik, infeksiyon, neyrodegenerativ və digər xəstəliklərdə tətbiqi.

- Kök hüceyrələrinin və məhsullarının prenatal müalicələrdə tətbiqi

- Kanser kök hüceyrələrinə təsir vasitələrinin axtarışı.

\section{Genomika}

\section{Dsaslandırma}

İyriminci əsrin sonunda insan genomunun açıqlanması genetik tədqiqatların geniş vüsət almasına, yeni elmi və praktiki biliklərin əldə edilməsinə böyük təkan verdi və XXI əsr "geneomika" əsri kimi qəbul edildi. İnsan orqanizmində baş verən fizioloji və patoloji proseslərin, ətraf faktorlara və müalicələrə cavabdakı müxtəlifliyin təməlində bilavasitə genlərin, gen aktivasiyasının və dəyişikliklərinin durduğuna əsaslanaraq insan sağlanmlığının qorunması, xəstəliklərin erkən diaqnsotikası, müalicə üsulunun seçilməsi, xəstəliyin və müalicə təsirinin proqnozlaşdırılmsı üçün genom tədqiqatları ön planda tutulmaqdadır. Hazırda bir çox klassik genetik xəstəliklərlə yanaşı süd vəzi, kolon, mədə, prostat, ağciyər xərçənginin, bəzi ürək, mədə-bağırsaq və digər xəstəliklərinin inkişafına yol açan ən önəmli genetik mutasiyalar və aktivləşən genlər (genomikslər) aşkarlanmış və bu nəticələr xəstəliyin diaqnostika, profilaktika, müalicə və proqnostikasında tətbiq edilməуə başlamışdır. Genetik nailyyətlər sayəsində farmakogenetika adlanan elmipraktik sahə yaranmışdır ki, bu da fərdin genetik polimorfiziminə əsaslanaraq həssas dərmanı və uyğun dozanı təyin etməyə imkan verir.

\section{Genom üzra piroritet təqiaqat mövzuları}

- Xəstəliklərin meydana gəlməsində və gedişində rol oynayan gen mutasiyalarını, polimorfizimini və genomiksləri ortaya çıxarmaq.

- Xəstəliklərin erkən diaqnostikasında, proqnozlaşdırlmasında və müalicəsində əhəmiyyəti olan gen mutasiyalarını, polimorfizimini və genomiksləri ortaya çıxarmaq.

- Perinatal gen diaqnostikası və gen müalicələri 
- Ekogenetika - ətraf mühitin təsirlərinə qarşı həssaslığın müəyyənləşdirilməsində rol oynanayan genetik variasiyaların araşıdırlması

- Neyro-genetika və davranış genetikası - beyin fəaliyyətlərinin tənzimində rol oynayan gentik variasiyaların öyrənilməsi

- Gen redaktəsi - xəstəliklərin profilaktikası və müalicəsi üçün genlər üzərində aparılan müdaxilələrin müsbət və mənfi nəticələrinin araşdılmısı.

- Farmakogenetika - dərmanlara həssaslığın müəyyənləşdirlməsində rol oynayan genetik variasiyaların ortaya çıxarılması.

- Bioinformatika - genetik məlumatların ekspressiyası üzrə tədqiqatlar.

\section{Molekulyar biologiya}

\section{Dsaslandırma}

Kiçik üzvi mollekulardan tutmuş mürrəkkəb quruluşlu nukleoproteinlərə və hüceyrə membranlarına qədər böyük arenanın əhatə edən və canlı sistemin təməlində duran molekulların funksiyalarını, biosintezini, qaraşııqlı təsirlərini və tənzimini öyrənən molekulyar biologiyanın insan sağlamlığında və xəstəliklərinin araşdırılmsında müstəsna rolu vardır. Müasir təbəbəti molekulyar biologiyasız təsəvvür etmək olmaz. Son illər bu sahədə əldə edilən nailiyyətlər sayəsində bir çox xəstəliklərin diaqnostika və müalcəsində yeni istiqamtələr yaranmış və sürətlə inkişaf etməkdədir. Məsələn, hüceyrədaxili və hüceyrəxarici reseptorlar və ligandaları, molekulyar requlyatorlar kimi mikro-RNT, sərbəst DNT-lər, histonlar, "molekul tomoqrafiyası" və s. bu qəbilədən olan yeni tədqiqat istiqamətləridir. Təsadüfü deyil ki, son illərdə tibb üzrə Nobel mükafatları molekulyar biologiyanın nailləyyyətlərinə əsaslanan DNT bərpası və hədəf müalicələrinə verilmişdir.

\section{Molekulyar biologiya üzra piroritet təqdqiqat mövzuları}

- Biomarkerlər- xəstəliklərin erkən diaqnostikasını, müalicələrə cavabını və proqnozladırılmasını həyata keçirmək üçün əməliyyətli olan molekulyar göstəriciləri ortaya çıxarmaq. 
- Hədəf müalicələri - fizioloji və patoloji proseslərin gedişində əhəmiyyətli rol oynayan bioloji molekulların blokadası və ya aktivləşdirliməsi

- Hüceyrə reseptorları - hüceyrənin səthində, sitoplazma və nüvəsundə yerləşən və proseslərin gdişində mühüm rol oyanayan qəbuledicilərin blokadası və ya aktivləşdirliməsi.

- Hüceyrədaxili siqnal istemləri - normal və patoloji vəziyyətlərdə hüceyrədaxili siqnal ötürücü sistemlərdə baş verən dəyişiklikləri ortaya çıxarma və onların korreksiya yollarının araşdırılması.

- Enzimlər - müxtəlif patologiyalarda hüceyrədaxili və hüceyrəxarici proseslərdə (siqnal ötürülməsi, sintez, deqradasiya, depolama, sekresiya və və s) iştirak edən fermentlərin struktur və aktivliyində baş verən dəyiikliklərin araşdırılması, diqnsotik və müalicə məqsədli istifadəsi.

- Proteomika - xəstəliklərin baş verməsində, diaqnostikasında və müalicəsində əhəmiyyətli rol oynayan proteinleri və protein komplekslərini ortaya çıxarmaq.

- Qeyri-genetik nuklein turşuları (mikro-RNT, sərbəst DNT və s) - fizioloji və patoloji proseslərin tənzimində rol oynayan qeyri-genetik nuklein turşuları araşıdırmaq, diaqnostika, müalicə və proqnozlaşdırmada rolunu ortaya çıxarmaq.

- Metabolomikslər- fizloloji və patoloji proseslərdə iştirak edən metabolizm məhsulları komplekslərini araşdırmaq, diaqnostika, müalicə və proqnozlaşdırmada rolunu ortaya çıxarmaq.

- Imflammasomlar - iltihabı proseslərdə rol oynayan regulyator və effektor molekulların araşırılması, diaqnostika, müalicə və proqnozlaşdırmada rolunu ortaya çıxarılması.

- İmmunomikslər - immun prosesləri həyata keçirən genetik və epigenetik molekul komplekslərinin araşdırılması, diaqnostika, müalicə və proqnozlaşdırmada rolunu ortaya çıxarılması.

- Biodeqradasiyon və bioinert materialların hazırlanması, sınaqdan keçirilməsi və klinik təbabətdə tətbiqi

\section{Translasyon təbəbət}




\section{Dsaslandırma}

Translasyon təbabət dedikdə fundamental təbabətdə əldə edilmiş nəticələrin klinik təbabətə tətbiq edilməsi nəzərdə tutulur. Son illər fundamental təbabətdə (biotəbabətdə) aparılan laborator və eksperimental tədqiatlarda fizioloji və patoloji proseslərin əsaslarına dair çoxsaylı elmi nəticələrin və yeni texnologiyaların əldə edilməşdir. Lakin bunların əksəriyyəti klinik təbəbətdə sınaqdan keçirilməmişdir. Ona görə də, hazırkı dövrdə dünya tibbinin qarşısında duran əsas tədqiqat istiqamətlərindən biri biotəbəbətdə əldə olunan nəticələrin insan xəstəliklərinin diaqnostikasında, müalicəsində, profilaktikasında və proqnozlaşdırmasında əhəmiyyətini ortaya çıxrmaqdır.

\section{Translasyon tababət üzra piroritet mövzular:}

- Insan genomu tədqiqatlarında əldə edilən elmi nəticələrin insan xəstəliklərində klinik əhəmiyyətini araşdırmaq.

- Molekulyar biologiyada əldə edilmiş elmi nəticələrin insan xəstəliklərində klinik əhəmiyyətini araşdırmaq.

- Biofizik, radiasion və nanobioloji tədqiqatlarda əldə edilmiş elmi nəticələrin insan xəstəliklərində klinik əhəmiyyətini araşdırmaq.

- Bioinformatikada əldə edilmiş elmi nəticələrin insan xəstəliklərində klinik əhəmiyyətini araşdırmaq.

- Hüceyrə, toxuma və orqan fiziologiyası və morfologiyası üzrə aparılan fundamental tədqiqatlarda əldə edilmiş elmi nəticələrin insan xəstəliklərində klinik əhəmiyyətini araşdırmaq.

\section{Yüksək texnologiyaların təbabətə tətbiqi}

\section{Osaslandırma}

Elmin ən son nailliyyətləri ilə əldə edilən ən yeni və təkmil cihaz və metodların istifadəsini əhatə edən yüksək texnologiyaların çoxsaylı növləri mövcudur. Bunlar arasında informasiya texnologiyaları, robotlar, görüntüləmə texnologiyaları, 
endoskopiya və nanotexnologiya təbəbətdə tətbiq edilməkdə və böyük perspektivləri görörünməkdədir.

\section{Yüksak texnologiyalar üzra piroritet mövzular}

- Xəstəliklərin diaqnostikası, müalicə seçimi, proqnozladırması və yeni dərman preparatlarının hazırlanması üçün süni intellekt və maşın öyrətmə proqramlarının hazııranması, sinaqdan keçirilməsi və tətbiqi.

- Xəstələrin məlumat bazasının yaradılması, nəticələrin operativ və obyektiv qiymətləndirməsi üçün proqram təminatının hazırlanması, sınaqdan keçirilməsi və tətbiqi

- Tibbi müəsisələrin idarə ediməsi üçün müasir proqram təminatının yaradılması.

- Elmi tədqiatların məlumat bazalarının yaradılması, toplanmış nəticələri məntiqi qiymətləndirmək üçün süni intellect təminatının hazırlanması, sınaqdan keçirlməsi və tətbiqi.

- 3D printer və artırılmış reallıq texnologiyalarının (kompyuterlə yaradılmış informasiyaların gerçək reallğa eynivaxtlı əlavə edilməsi) - naviqasyon cərrahiyyə cərrahi praktikada sınaqdan keçirilməsi və klinik əhəmiyyətinin araşdırılması.

- Biotexnologiyanın imkanlarından istifadə edərək yeni dərmanların sintezinə nail olmaq

- Yeni görüntüləmə texnologiyalarının (PET-KT, orqanspesifik kontrastlı MRT və USM, elastoqrafiya, 3D-rekonstruksiya, NiRS-yaxın infraqırmızı spektroskopiya və s.) xəstəliklərin diaqnostika və proqnozlaşdılmısında əhəmiyyətinin araşdılıması.

- Elektro və digər stimulyasiya cihazlrının vasitəsi ilə azan sinirlərin sitmulyasiyasının iltihabı və degenerativ xəstəliklərdə rolunun araşdırıması

- Robotik, endoskopik və azinvaziv texnologiyalarının diaqnostik və müalicəvi əhəmiyyətinin araşdırımıası.

- Mikrocip texnologiyalarının diaqnostikada və müşahidə məqsədli tətbiqinin qiymətləndirlməsi. 


\section{Biofizika}

Məlumdur ki, bütün xəstəliklərin təməlidə biomolekulların, hüceyrələrin və orqanların funksiyonal pozulması dururur, funksiyalar isə molekul və hüseyrələrin fiziki xüsusiyyətlərdən bilavasitə asılıdır. Digər tərəfdən xəstəliyin özü də orqanizmin ayrı-ayrı komponentlərində fiziki dəyişikliyə gətirib çıxara bilir. Səbəb və ya nəticə olmasından asılı olmayaraq, istənilən patoloji prosesdə biomolekulların və hüceyrələrin fiziki xüsusiyyətlərində (miqdar, quruluş, su ilə qarşılıqlı təsir, elastiklik, elektomqanetik, fotodinamik vəs.) mütləq dəyişiklik meydana gəlir. Ona görə də bu fiziki dəyişkiliykləri öyrənməklə xəstəliklərin səbəbini, müxanimlərini araşdırmaq, diqnostika və müalicə imkanlarını ortaya çıxarmaq müasir təbəbətin fundomental təqiqat istiqamətlərindən sayılır. Aşağıdakı biofizika tədqiatlar piroritet istiqamətlər kimi tövsiyə edilə bilər:

- Hüceyrəxarici və hüceyrədaxili zullararın, nuklein turşularının strukturunda və fiziki xassələrində verən dəyişikliklərin öyrəniulməsi, xəstəliklərin diaqnostikasında və müalicəsində əhəmiyyətinin araşdırılması.

- Hüceyrəxarıcı və hüceyrədaxili reseptorlarda və siqnal sistemlərində baş verən struktur və fiziki dəyişikliklərin örənilməsi və xəstəliklərin diaqnostikasında və müalicəsində əhəmiyyətinin araşdırılması.

- Hüceyrələrin və hücyrə membranlarının fiziki xüsusiyyətlərində baş verən dəyişikliklərin öyrənilməsi və xəstəliklərin diaqnostikasında və müalicəsində əhəmiyyətinin araşdırılması.

- Nanozərrəciklərin, nanomebranların, plazmonların yaradılması, xəstəliklərin diaqnostikasında və müalicəsində əhəmiyyətinin araşdırılması.

- Fiziki vasitələrin, xüsusən, işıq, radiasiyon, elektromaqnit dalğalarının xəstəliklərin diaqnsotika və müalicəsində rolunun araşdırılması.

\section{Subutlu təbabət}

Son iyrimi ildə elmi və praktik təbabətdə baş verən köklü dəyişikliklərdən biri də məhdud təcrübəyə və nəzəri əsaslara dayanan klassik təbabətin müasir sübutlu təbabətlə əvəz edilməyə başlamasıdır. Çoxmərkəzli, randomizə və dəqiq kriteriyalı tədqiqatlarla isbat olunmuş nəticələrə əsaslanan sübutlu təbabət həm rutin tətbiq 
edilən, həm də yeni diaqnostika və müalicə üsullarının səmərəliliyini qiymətləndirməyə imkan verir.

- Müasir səviyyədə düzənlənən çoxmərkəzli tədqiatlarla ekoloji, təbii və süni risk amillərinin sağıamlığa, xəstəliklərə və həyat keyfiyyətinə effektini ortaya çıxramaq.

- Müasir tələblərə uyğun düzənlənən (randomizasiyaya, homogenlik, ölçüləbilən və dəqiq müqayisə kriteriyaları) çoxmərkəzli klinik təqdiqiatlarla hazırda geniş tətbiq edilən klassik diaqnostika, müalicə, profilaktika və proqnozlaşdırma üsullarının tibbi, mənəvi və iqtisadi səmərəliliyinin araşdırıması.

- Müasir tələblərə uyğun düzənlənən (randomizasiyaya, homogenlik, ölçüləbilən və dəqiq müqayisə kriteriyaları) çoxmərkəzli klinik təqdiqiatlarla yeni diaqnostika, müalicə, profilaktika və proqnozlaşdırma üsullarının tibbi, mənəvi və iqtisadi səmərəliliyinin araşdırılması.

\section{Yeni dərman preparatlarının və fiziki müalicə üsullarının hazırlanması}

Dərman sənayesi dünyada sürətlə inkişaf edən sahələrdən biridir və demək olar ki, hər gün yeni dərman istahsal edilməkdədir. Buna baxmayaraq, yan təsirləri az, effektivliyi isə yüksək olan və təbii əsaslı dərman preparatlarına ehtiyac davam etməkdədir. Dərman sənayesində önəmli istiqətlərdən biri təbii və bioloji əsaslı preparatların istehsalıdır. Ölkəməzin bitkilərlə, minerallarla, təbii karbohidratlarla zəngin olduğunu nəzərə alaraq yerli xammal əsasında yeni dərman

preparatlarının istehsalı, eksperimental və klinik sınaqlardan keçirilməsi piroritet istiqamət kimi tövsiyə edilir.

Bu sahədə tövsiyə edilən konkret istiqamətlər:

- Yerli yabanı bitkilər əsaında yeni dərman preparatlarının hazırlanması

- Yerli mineral-karbohidrat mənşəli xammaların (palçıq vulkanları, mineral sular, naftalan və s) müalicəvi effektlərinin araşdırılması

- Xalq təbabətinə istfadə edilən müalicə üsullarının klinik təbəbətdə sınaqdan keçirilməsi (fitonirinq) 


\section{Mikrobiotanın və mikrobiomların öyrənilməsi və tətbiqi}

İnsan orqanizminin xarici mühitlə birbaşa təmasda olduğu nahiyyələrində, xüsusilə dəridə, üst tənəffüs yollarında və mədə-bağırsaq sistemində müxtəlif növlü 100 trilyondan çox bakteriyalar mövcudur. İnsan orqanizmi ilə simbioz şəkildə yaşayan bu bakteriyalar kompleksi (mikrobiota) immun sistemi stimulyasiya edəir, patogen bakteriyaların inkişafının qraşısını alır və mühüm müdafiə funksiyası yerinə yetirir. Bu mikrobalrın gen tərkibi isə mikrobiom adlanır. Son illərki tədqiatlar göstəriri ki, vücuddakı mikrobiotanın tərkibində baş verən kəmiyyət və keyfiyyət dəyişiklikləri nəinki infeksiyon, həmçinin bəzi qeyri-infekiyon xəstəliklərin baş verməsində mühüm rol oyanyır. Məsələn, sirrozda, piylənmədə, bəzi autoimmun, allergik və nerodegenerativ xəstəliklərdə mikrobiotanın rolu olduğu göstərilmişdir. Bunları nzərə alarıaq aşağıdakı istiqamət aktual ola bilər:

- Qeyri-infeksiyon xəstəliklərin və tibbi müdaxilələrdən sonrakı ağırlaşmaların patogenezi və gedişində mikrobiotanın rolunun araşıdırıması

- Mikrobiotanın qorunması və dəyişikliklərinin korreksiyası üçün yeni müalicə üsullarının axtarışı.

- Toplumda patoloji və fizioloji proseslərin gedişi, yayılma xüsusiyyətlərinin öyrənilməsi (epidemioloji təqdiqatlar)

\section{PRINSIPLOR}

Müasir tədiqatlarda ən çox tövsiyə ediən üç əsas prinsip aşağıdakılardır:

- Innovativlik

- Multidisiplinarlıq

- Çoxmərkəzlilik

\section{PIRORITET SAHOLəR}

Aşağıdakı öncül sahələrdə yuxarıda qeyd edilən piroritet istiqamətlər üzrə elmi tədqiqatların aparılması tövsiyə edilir: 
- Onkoloji xəstəliklərin profilaktikası, erkən diaqnostikası və müalicəsi

- Ürək-damar xəstəliklərinin profilaktikası, erkən diaqnostikası və müalicəsi

- Endokrin və metabilok epidemiyalar (diabet, piylənmə, insulinorezistentlik)

- Ağciyər xəstəliklərinin profilaktikası, erkən diaqnostikası və müalicəsi

- Hepatologiya və qastroenterologiya

- Nevroloji xəstəliklərin profilaktikası, erkən diaqnostikası və müalicəsi

- Uşaq xəstəliklərinin profilaktikası, erkən diaqnostikası və müalicəsi

- Psixatrik xəstəliklərin profilaktikası, erkən diaqnostikası və müalicəsi

- Immunologiya

- Mikrobiologiya və infekiyon xəstəliklər

- Farmakologiya

- Profilaktik təbabət

- Reproduktiv təbabət

- Herintologiya

- Transplantasiya

- Ekologiya və insan sağlamlığı

- Epidemioloji və sosioloji tədqiqatlar

- Digər tibbi problemlər

\section{Azərbaycan Respublikası Elmi Tədqiqatların Olaqələndirilmə Şurasının Klinik, Regenerator və Translyason Təbabət üzrə Elmi Şurasının Sədri}

AMEA-nın müxbir üzvü, Professor Nuru Bayramov

\section{Elmi katibi}

tibb elmləri doktoru Rasim Cəfərli 